\title{
Toward Truthlikeness in Historiography
}

\author{
Oliver Laas
}

\section{OpenEdition}

\section{Journals}

Electronic version

URL: http://journals.openedition.org/ejpap/643

DOI: 10.4000/ejpap.643

ISSN: 2036-4091

\section{Publisher}

Associazione Pragma

\section{Electronic reference}

Oliver Laas, «Toward Truthlikeness in Historiography », European Journal of Pragmatism and American Philosophy [Online], VIII-2 | 2016, Online since 16 January 2017, connection on 21 April 2019. URL: http://journals.openedition.org/ejpap/643; DOI : 10.4000/ejpap.643

This text was automatically generated on 21 April 2019

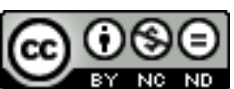

Author retains copyright and grants the European Journal of Pragmatism and American Philosophy right of first publication with the work simultaneously licensed under a Creative Commons AttributionNonCommercial-NoDerivatives 4.0 International License. 


\title{
Toward Truthlikeness in Historiography
}

\author{
Oliver Laas
}

\section{AUTHOR'S NOTE}

I would like to thank the editors of the European Journal of Pragmatism and American Philosophy for their patience, and two anonymous reviewers whose comments vastly improved the quality of this essay.

\section{Why Truthlikeness?}

1 According to the realist view, inquiry begins with a cognitive problem that has the form of a question. An answer expresses a proposition about the world or a part of it, whether present, past or future, and is the overall goal of inquiry. Answers can be partial or complete (Niiniluoto 1987: 203, 129-30). A complete answer to a cognitive problem is the whole truth. Thus, we might say that the (or a) goal of inquiry is the truth. Call this the truth doctrine. Optimism suggests that the history of science is a progress toward this aim by way of increasingly accurate theories - call this the progress doctrine (Oddie 1986:1). But fallibilism holds that our theories are generally false or likely to be false, and are, after falsification, replaced with other theories that are also likely to be false. ${ }^{1}$ One motivation for the notion of truthlikeness in science is the desire to be an optimistic fallible realist about inquiry (Niiniluoto 1987: 156; Oddie 2014).

2 Another motivation is to account for our seeming ability to grade various propositions in different situations according to their closeness to the truth within those situations. Compare:

1) The number of planets in our solar system is 9.

2) The number planets in our solar system is 900 . 
Intuitively, (1) is closer to the truth than (2), implying that one falsehood can be closer to the truth than another. Consider another pair:

3) The number of planets is between 7 and 9.

4) The number of planets is greater than 0.

4 (3) seems closer to the truth than (4), implying that some truths are closer to the whole truth than others (cf. Oddie 2014). Similar comparisons are possible for qualitative propositions.

5 Finally, it seems that sometimes a false theory can achieve the aims of inquiry better than a true one that is more limited in scope.

There may be topics where the best we can do is not to arrive at propositions that are true but to arrive at propositions that are as little false as possible. [...] Some false propositions may be far more worth asserting, may be of far more importance for developing a less incorrect view of reality or parts of reality than hosts of true propositions of less range and significance. (Ewing 1934: 226-7)

A notion of truthlikeness should be able to show how this is possible.

Discussions of truthlikeness have largely been limited to natural science. One reason for extending the concept to historiography is that this would allow us to be optimistic fallible realists about historiography.

\section{Realism, Skepticism, and the Fundamental Ontological Tradeoff}

8 In the face of disagreements over notions like evidence, we might define historical knowledge as the analysis of extant evidence with the aim of drawing inferences about history, that is, past events (Tamm 2014: 285-6; Tucker 2006: 1). Historiography consists of representations of past events, since historians cannot observe them. Hence historiography is not the study of past events, but the study of traces of the past; it is the art of reasoning from traces to facts (Tucker 2006: 1, 93).

There are two positions about the relationship between historiography and history: realism and constructionism. The latter can support some version of anti-realism, but does not necessarily entail it, since something can be constructed in the present and be a true account of the past. Let's say that general realism about some subject matter or field of inquiry is the following thesis:

(GR) General Realism: Given $a, b, c, \ldots$ as the distinctive objects of a subjectmatter, and $F, G, H, \ldots$ as distinctive properties of these objects, then it is the case that

(EC) The existence claim: $a, b, c, \ldots$ exist and have properties such as $F, G, H, \ldots$; and

(IC) The independence claim: the existence of $a, b, c, \ldots$, and their having the properties $F, G, H, \ldots$ is independent of anyone's beliefs, linguistic practices, conceptual schemes, and so on.

10 In short, realism ascribes objective, mind-independent existence to various objects and properties, such as the external world, mathematical objects, or the past. The world is as it is, independently of what anyone else thinks about it (Miller 2014). 
11 Although realism can be accepted or rejected across the board, it is more common to be selectively realist or non-realist about various topics. For example, one can be a realist about everyday macroscopic objects but an anti-realist about abstract objects like numbers.

In turn, anti-realism in the broad sense could be defined as the following thesis:

(GAR) General Anti-Realism: Given $a, b, c, \ldots$ as the distinctive objects of a subject-matter, and $F, G, H, \ldots$ as the distinctive properties of these objects, then it is the case that either

(NEC) The negative existence claim: $a, b, c, \ldots$ do not exist and/or do (not) have properties $F, G, H, \ldots$; or ${ }^{2}$

(DC) The dependence claim: the existence of $a, b, c, \ldots$, and their having the properties $F, G, H, \ldots$ is dependent on people's beliefs, linguistic practices, conceptual schemes, and so on.

Anti-realism denies the objective, mind-independent existence of objects and properties affirmed by realism in a particular domain or with respect to some subject matter.

Semantic realism retains EC from GR but reformulates IT in terms of the principle of bivalence: every meaningful sentence about $a, b, c, \ldots$, having or not having $F, G, H, \ldots$, is either true or false independently of whether we are or will ever be able to ascertain this. Anti-realists deny bivalence (see Dummett 1959, 1978, 1983, 1991). Note that this characterization of realism is controversial. Realism requires the objective independent existence of those entities that make statements about them true. Semantic realism says nothing about the nature of the reality that makes such statements true or false (Devitt 1983: 77). Thus, semantic realism is not equivalent to realism, since realism "says nothing semantic at all beyond [...] making the negative point that our semantic capacities do not constitute the world" (Devitt 1991: 39).

Realism about historiography claims that historiography is a representation of history, that historiography is a true account of past events. Historiography interprets or explains historical evidence to infer from present traces to past events (Murphey 1973, 1994; Tucker 2006: 255). Constructionism claims that historiography is a construction in the present, not a representation of the past. Historiography does not refer to history because sentences about the past are neither true nor false; they have no truth value because they have no clear truth conditions. Since the past is inaccessible, all we have are historians' present constructions. Any further metaphysical assumptions about the reality of the past are unwarranted (Tucker 2006: 255-6). The most extreme form of constructionism is skeptical constructionism or historiographic skepticism which claims that there is no knowledge of history because historiography is ontologically and epistemically indistinguishable from literary fiction (ibid.: 256). This view rests on the postmodern challenge (so-called because its most prominent supporters, like Roland Barthes and Hayden White, either were or drew heavily from post-structuralist and postmodernist thinkers). ${ }^{3}$ The epistemic side of the challenge asks how textual and archaeological evidence warrants truth apt assertions about the past. The semantic side concerns whether signs in general, and textual evidence in particular, can refer to a language-independent past. There seems to be a connection between semantic realism and realism about historiography since our access to the past is largely mediated by (written) evidence, and if such evidence cannot be true or false, then we cannot justifiably make inferences about the past on the basis of present evidence. 

the fundamental ontological tradeoff, a tension between explanatory power and epistemic risk: a rich ontology has greater explanatory power but a modest ontology is epistemically safer. The more ontological machinery we postulate, the more we might be able to explain, but the harder it is to believe in the existence of all the postulated entities and relations (Swoyer \& Orilia 2011). The strengths of anti-realism in general, and constructionism in particular, are simplicity and epistemic safety, since they make fewer assumptions than historiographical realism. The strength of realism is explanatory power, because it is a better explanation of consensus about historical facts, theories, and methods among a large, uncoerced, and heterogeneous group of historians (Tucker 2006: 257). issues. The first of these is realism and anti-realism about meaning in historiography. Historiographical texts employ proper names (Julius Caesar), names of institutions (the Roman senate), and abstract concepts (revolution). Do such expressions refer to entities that actually existed in the past? It is conceivable that they existed independently of historians' representations (EC) but that the past is nonetheless constructed from their representations (DC). Secondly, there is the issue of the epistemic status of historiographical explanation. The aforementioned concepts are based on present evidence of the past. Such evidence can be missing, erroneous or sometimes require distance to be properly understood. This casts doubt on the notion that the concepts found in historiographical texts refer to past existents. Third, there is the ontology of history. The different kinds of expressions and concepts employed in historiographical texts suggest different kinds of ontologies: proper names seem to require the existence of past individuals, institutional names the existence of institutions, and abstract terms the existence of kinds. ${ }^{4}$ All of these issues cannot be dealt with in this paper since each would require further investigation. What I have to say will touch mainly on realism and antirealism about meaning, but not on the epistemology and specific ontology of historiography. I will draw on Charles S. Peirce's semeiotics, logic, and philosophy of science to provide a metaphysically modest ground upon which a concept of truthlikeness in historiography can be established. This would open the way to optimistic fallibilist realism about historiography.

\section{Desiderata for a Concept of Truthlikeness in Historiography}

Before a measure of truthlikeness can be defined, we need to know the requirements that such a measure should fulfill. There is no prima facie good reason to suppose that a measure suitable for theories in the natural sciences can be expanded without modification to the human sciences. Hence we should examine the characteristic features of historical knowledge and its acquisition in order to see which modifications, if any, are in order.

Realism seems to be connected with the correspondence theory of truth, since it requires an objective relation of reference between expressions and the world (see Putnam 1978: 18). The correspondence theory claims that a proposition is true if it corresponds to the way things actually are, that is, to the facts. The correspondence theory has been 
criticized on numerous grounds over the years. Instead of reviewing the objections I will simply remark that, prima facie, the correspondence theory faces additional difficulties when extended to historical knowledge. Such knowledge is neither based on nor corroborated by observations of historical events. Historical facts are not given. Historiography presents descriptions of such events on the basis of evidence. It "is a science whose business is to study events not accessible to our observation, and to study these events inferentially, arguing to them from something else which is accessible to our observation, and which the historian calls 'evidence' for the events in which he is interested" (Collingwood 1956: 251-2).

Historical events transfer information through evidence because each event generates numerous informational signals, most of which are gradually lost or corrupted over time. Historians attempt to extract information about historical events from the evidence by separating later additions and distortions from the original signal (Kosso 1992: 32-3; Tucker 2006: 18). The relationship between historiography and evidence is similar to the relationship between theory and evidence in other sciences: descriptions of historical events in historiography are akin to descriptions of unobservable entities, like electrons, in physics, since both are grounded in inferences based on publicly observable evidence the former on written documents, the latter on instrumental measurements (Kosso 1992; Murphey 1973: 16).

21 Methods for producing historical knowledge are communal in the sense that there is a large, uncoerced, heterogeneous community of historians who agree on acceptable means of obtaining evidence, strategies for using said evidence, conventions for conducting disagreements, and shared assumptions about the division of labor in inquiry (Tucker 2006: 6, 20ff). Historians construct explanatory hypotheses to explain the evidence, and use evidence to confirm hypotheses (Goldstein 1996: 9-10). The evidence must be interpreted before it can support explanatory hypotheses. Interpretative judgments serve partly as organizing principles for describing past events, and criteria of relevance for the selection of additional evidence in support of explanatory hypotheses (cf. Stalnaker 1967: 176). Since explanations of historical evidence can be wrong, historical knowledge is fallible (Tucker 2006: 257).

Thus, a realist account of historical knowledge that would support a notion of truthlikeness in historiography must be fallibilist, closely related to inquiry, include the communal aspect of inquiry, account for the interpretative practices involved in inquiry, and allow for some kind of causal informational link (e.g. by way of reference) between past events and their present traces. Thus, to establish a concept of truthlikeness in historiography, we need at least three things:

1) a referential theory of meaning, because this supports realism by explaining how statements about the past can be true or false due to being about actual past event;

2) a fallibilist account of inquiry;

3) an account of truth that leaves room for progress toward the truth, and accounts for the role of consensus in the whole process.

The underlying realism should be modest in order to successfully compete with antirealist alternatives while retaining its explanatory advantage. I will argue that Peirce's semeiotics and pragmatist theory of truth, when interpreted dialogically, provide a modestly realist basis from which to develop an account of truthlikeness in historiography that satisfies the three desiderata outlined here. 

postmodern challenge because if it stands, then realism about historiography is untenable. I will focus on its semantic aspect, mentioning the epistemic aspect only in passing because it has already elicited a number of novel replies. The semantic aspect rests on a conflict between competing theories of meaning: realists insist that sentences receive their meaning from their relations with the world; skeptics subscribe to the view that sentences receive their meaning from their relations with other sentences (Tucker 2006: 7-8). I will defend realism by challenging the arguments of Roland Barthes and Hayden White, the two main proponents of the postmodern challenge.

\section{The Postmodern Challenge}

Modern historiography rests on two methodological presuppositions:

- The ontological presupposition: the past is real, what happened did formerly exist, and the nonpresence of the past (and of the future) cannot be identified with its unreality (Françoise Châtelet, quoted in Le Goff 1992: 10).

- The epistemological presupposition: every discourse about the past must be able to rigorously show, on the basis of evidence, why it proposes a particular sequence of events rather than another (ibid.: 11).

The historian's knowledge of the past is indirect. Texts and archaeological sources only give answers to the questions we pose to them. The historian's work begins by posing a question which expresses his or her cognitive problem (cf. Bloch 1953: 48-50, 53-4, 64-6).

The postmodern challenge is a challenge to the scientific status of historiography. It replaces the question "How is history like science?" with the question "How is history like and unlike fiction?" as one of the main issues in the philosophy of history. It rests on two theses:

- Anti-representationalism: the past cannot be the referent of historical statements and representations (Zagorin 1999: 13).

- Narrativism: the fictional stories invented by writers and the narrations crafted by historians do not differ in any essential respect (ibid.: 14).

Anti-representationalism does not entail that constructivists are all anti-realists who deny the existence of reality. They claim that the reality referred to by signs is ultimately inaccessible to us due to innumerable mediations between us and the sign's referent (Jenkins 2000: 187). The postmodern challenge undermines the apparent obviousness of modern historiography's two methodological presuppositions whereas realism would uphold them.

\section{Barthes' Argument for Anti-Representationalism}

In his 1967 essay, "Le discours de l'historie," Roland Barthes gave an influential argument for anti-representationalism, which can be summarized as follows:

1) Language is incapable of referring to anything outside itself, such as the world, reality, or the past. 
2) Both historiography and narrative fiction employ the reality effect, creating a referential illusion of apparently being about reality, while actually replacing the text's referent with narrative.

3) History appropriates narrative structures from fiction, where these were originally developed.

4) Therefore, narrative history is indistinguishable from narrative fiction (cf. Doležel 2010: 16-9).

The first premise rests on structuralist literary theory and poststructuralist philosophy of language (Doležel 2010: 16). Both draw on Ferdinand de Saussure's semiology which rests on a dyadic sign model according to which a sign is a composite entity made up of two elements, the signifier and the signified, held together by the signification relation:

signifier

signified

31 For Saussure (1959: 66-7), the signifier was a sound-image. Subsequent semioticians treated it as a material sign-vehicle, e.g. a sound, a printed letter, a gesture, and so on. The signified is the conceptual part of the sign - a mental entity, image or concept (Sebeok 2001: 5-6). A sign's meaning is constituted by its language-internal relations of opposition with other signs in the language (Saussure 1959: 88). There are two kinds of internal relations: syntagmatic relations between signs that can be conjoined in well-formed strings called syntagms (e.g. the relation between "the king" and "approves" since they can be conjoined into "the king approves"), and paradigmatic relations between a sign and its possible alternatives in well-formed syntagms (e.g. the relation between "approves" and "disproves" because the latter can replace the former) (Devitt \& Sterelny 1999: 262). This leads to a holistic view of language. The meaning of a sign is defined by its relations to all other signs, by its place in the entire structure (Saussure 1959: 22). Language is an autonomous system that is to be explained on its own terms, without any reference to anything outside its structure (Hawkes 1977: 16-7). Reference is a relation between a sign and the object it represents, the referent. As a concept, the signified is determined entirely by language-internal syntagmatic and paradigmatic relations without any reference to language-external entities (Saussure 1959: 111-2; cf. Jameson 1972: 105-6; Hawkes 1977: 17). Post-structuralists, many of whom were not linguists, have interpreted Saussure's holistic view in an anti-referentialist way. There seem to be at least two reasons for rejecting reference in the post-structuralist literature. First, signification is arbitrary because it rests on a convention maintained by the linguistic community (Saussure 1959: 67). There is no natural connection between signifier and signified (ibid.: 68-9). The assumption seems to be that arbitrariness undermines reference, and hence that a relational analysis is the only viable alternative (Devitt \& Sterelny 1999: 267). Secondly, there is the argument from color terms: the signified of a color term, such as "brown," does not include reference because color terms cannot be taught by the presentation of, say, brown objects.

It is only when he [the pupil] has grasped the relation between brown and other colors that he will begin to understand what brown is. [...] the signifieds of color terms are nothing but the product or result of a system of distinctions. (Culler 1976: 25)

Thus, the referential dimension of language is denied. Some authors have gone so far as to talk of a "referential fallacy" that results from substituting reality for its 
representation. ${ }^{5}$ Barthes draws on semiology when he claims in his first premise that language cannot refer to anything outside itself.

The second premise claims that historiography and narrative fiction are similar in that both employ the reality effect and create the illusion of reference to extra-linguistic reality. The reality effect is a complex operation that involves two phases. In the first phase, "the referent is detached from the discourse, it becomes exterior to it, grounds it, is supposed to govern it: this is the phase of res gestae, and the discourse simply claims to be historia rerum gestarum" (Barthes 1967: 138). In the second phase, the signifier is replaced with the referent. In this, historiography resembles the historical novel where concrete details, such as descriptions of the setting or costumes, are also constituted by the "direct collusion of a referent and a signifier" (Barthes 1968: 147-8). As a result "this same 'reality' becomes the essential reference in historical narrative, which is supposed to report "what really happened"' (ibid.: 146). The reality effect consists in "the very absence of the signified, to the advantage of the referent alone, [which] becomes the very signifier of realism" (ibid.: 148). From the perspective of narrative structure, such details are superfluous, but they serve to create the referential illusion of an objective discourse where history narrates itself (Barthes 1967: 131-2). Historical facts have only linguistic existence, but because of the referential illusion, such facts seem to be anterior to historiography (ibid.: 138). Hence historiography and narrative fiction are similar in that both rely on the reality effect to create the referential illusion that the discourse in question refers to reality.

The third premise of Barthes' argument is that history appropriates narrative structures from fiction, where they were originally developed: "narrative structure, elaborated in the crucible of fictions (through myths and early epics), becomes both sign and proof of reality" (Barthes 1967: 140). His conclusion is that narrative history and narrative fiction are indistinguishable. Historical discourse is "essentially an ideological elaboration or, to be more specific, an imaginary elaboration" (ibid.: 138).

Barthes' views fail to satisfy the three desiderata for the notion of truthlikeness set out above: his theory of meaning rejects reference, equating historiography with fiction leaves no room for truth, and this leads to skepticism, not fallibilism about historical knowledge. Barthes' conclusion must be challenged in order to make way for a concept of trutlikeness in historiography.

Barthes' argument has numerous weaknesses that the realist could exploit in mounting a counterattack. First, one could challenge the first premise. The arbitrariness of signification is not a sufficient reason for rejecting reference. The structuralists seem to presuppose that the only possible theory of reference is a naïve picture theory according to which signs are "pictures" of things: if signs are "pictures," then their relation to their referents is not arbitrary - they would be constrained by their likeness to their referents; if signification is arbitrary, then signs cannot be "pictures" of their referents; signification is arbitrary; thus, signs are not pictures and cannot refer (Devitt \& Sterelny 1999: 267). Evidence for this presupposition can be found in structuralist writings:

There exists no necessary "fitness" in the link between the sound-image, or signifier 'tree,' the concept, or signified that it involves, and the actual physical tree growing the earth. The word 'tree,' in short, has no "natural" or "tree-like" qualities [...]. (Hawkes 1977: 25)

But arbitrariness and reference can be compatible. Reference does not involve picturing; it could instead be understood along causal lines (Devitt \& Sterelny 1999: 267).

European Journal of Pragmatism and American Philosophy, VIII-2 | 2016 
argument from color terms is implausible. First, it is unlikely that an organism incapable of discriminating between brown and other colors would be able to acquire the concept of brown. But even if learning color terms involves nothing above and beyond learning their language-internal differences from other color terms, it does not follow that color terms do not refer or that their reference depends on other color terms in the language. What is required for learning reference is one thing; what reference consists in, is another (Devitt \& Sterelny 1999: 268). Second, cross-linguistic surveys of color terminology have shown that while languages do differ in the number and extensional range of their color categories, the amount of cross-linguistic diversity is notably reduced when speakers of different languages are asked to identify "good examples" of their color words, such as a "good red." Speakers then tend to select colors from a very limited area of the color spectrum. This suggests that there is a universal set of focal colors, from which different languages make their selection. Furthermore, the lexicalization of color terminology in different languages shows notable uniformities: black, white, and red are generally lexicalized first, while pink, purple, and grey appear last (Berlin \& Kay 1969). The existence of a small number of relatively universal focal colors is also supported by evidence from cognitive psychology (see Heider 1971, 1972).

The rejection of reference encourages anti-realism, because access to a languageindependent reality by way of signs becomes problematic if the referential relation between sign and world does not have any bearing on the sign's meaning. While semiology does retain some notion of reality, since the signified as a concept is a concept of something (Jameson 1972: 106), this something is a reality created by language itself (cf. Hawkes 1977: 26, 149). While the poetic, world-making powers of language cannot be denied (cf. Goodman 1978), overemphasizing them leads to the view that (human) reality is language-dependent (cf. Hawkes 1977: 28), that the language-independent world is a mysterious and inaccessible "formless chaos of which one cannot even speak in the first place," (Jameson 1972: 33) and to relativism which claims that different autonomous sign systems create different, independent and incompatible realities (Hawkes 1977: 56). The corollaries of this view of language are the inaccessibility of the past, and an understanding of historical discourse as analogous to fiction-making in that it creates the past it surreptitiously purports to be about.

\section{White's Argument for Narrativism}

Hayden White has given a prominent argument for the narrativist thesis. His research into how elements of narrative discourse function in historiography was influenced by Barthes. In fact, White's approach draws explicitly from poststructuralist philosophy of language, and embraces its constructivist implications:

Historical accounts purport to be verbal models, or icons, of specific segments of the historical process. But such models are needed because the documentary record does not figure forth an unambiguous image of the structure of events attested in them. In order to figure "what really happened" in the past, therefore, the historian must first prefigure as a possible object of knowledge the whole set of events reported in the documents. This prefigurative act is poetic inasmuch as it is precognitive and precritical in the economy of the historian's own consciousness. It is also poetic insofar as it is constitutive of the structure that will subsequently be imaged in the verbal model offered by the historian as a representation and explanation of "what really happened" in the past. But it is constitutive not only of a

European Journal of Pragmatism and American Philosophy, VIII-2 | 2016 
domain which the historian can treat as a possible object of (mental) perception. It is also constitutive of the concepts he will use to identify the objects that inhabit the domain and to characterize the kinds of relationships they can sustain with one another. In the poetic act which precedes the formal analysis of the field, the historian both creates his object of analysis and predetermines the modality of the conceptual strategies he will use to explain it. (White 1973: 30-1) a literary operation employed by both historiography and literature, and literature is fiction. His argument for the narrativist thesis can be summarized as follows:

1) Emplotment is a literary operation employed in historiography.

2) Emplotment is a literary operation employed in literature.

3) Literature is fiction.

4) Therefore, historiography is equivalent to fiction-making (cf. Doležel 2010: 21).

The first premise, that emplotment is employed in historiography, rests on White's views on how historical discourse achieves its "explanatory effect." Historiography is a threestaged process. First, a chronicle is formed from the elements in the historical field comprised of historical events. Chronicles are open, without beginning nor end, because they begin when the chronologist starts recording events, and stop when he does (White 1973: 5, 6). Second, the chronicle is transformed into a story through motifical encoding. A story, unlike a chronicle, is a unit demarcated by a beginning and an ending. Historians do not find stories in chronicles; they invent them because one and the same event, for instance, the king's death, can function as an inaugural, transitional, or terminating motif in different historical narratives. It is the historian who, in crafting a historical narrative, decides which of these roles a particular event plays in his or her account of the past (ibid $\therefore$ 5-7). Third, the newly formed narrative unit is subjected to one of three modes of explanation: explanation by emplotment, explanation by argument, or explanation by ideological implication. Inspired by Northrop Frye (1957), White distinguishes four ways of emplotment, and derives from them four "archetypal" forms of historical narrative: tragedy, comedy, satire, and romance. Every historian is compelled to emplot his text according to one of these four forms (White 1973: 7-8).

The second and third premises claim that emplotment is a fiction-making operation because it is also employed in literature, and literature is fiction. This is explicitly laid out in White's Tropics of Discourse, where he writes that history is the matching of "a specific plot structure with the set of historical events that he [the historian] wishes to endow with a meaning of a particular kind," (White 1978: 85 ) and adds that "[t]his is essentially a literary, that is to say fiction-making operation" (ibid.). This establishes the double equation at the core of the narrativist thesis

emplotment $=$ literary operation $=$ fiction - making

It is set up by a substitution of terms that White treats as synonymous. He concludes that historiography is equivalent to fiction-making. Subsequent writers have relied on this double equation to make even more radical claims about history, viz. that history is invented (Munslow 1997: 118, 178) and that history is ending (Jenkins \& Munslow 2004: 2).

White's views, too, go against the three desiderata set out above, since he denies both reference and truth, and seems to support skepticism about historical knowledge by equating historiography with fiction. The realist could attack White's argument in a number of ways. First, even though emplotment is employed in both literature and 
history, there are crucial differences between fictional and historiographical texts. Narratives in fiction and narratives in historiography differ in their purpose: the latter purport to be true, and can therefore be doubted or turn out to be false, while the former are not supposed to be true, are therefore not supposed to be doubted and cannot turn out to be false (Van den Akken 2013: 349).

Second, factual narratives advance claims of referential truthfulness while fictional narratives do not. This difference becomes apparent when we compare factual with forged narratives. Both claim to be true, but the latter, when uncovered, is deemed false, not fictional. One cannot falsify a fictional narrative in the way one can falsify a forgery (Tamm 2014: 277-8). More specifically, we can distinguish between world-imaging texts (I-texts) and world-constructing texts (C-texts). I-texts are representations of the actual world and provide information about it. The world itself exists prior to and independently of I-texts. C-texts are the results of world-making practices that construct the worlds represented in them. Such texts exist prior to the world they describe. Literary and fictional texts are C-texts. I-texts are truth-apt while C-texts are not (Doležel 1998: 24). Historical texts are I-texts. Their goal is to express propositions that carry information about the actual world at some time in the past. Such propositions are made true or false by the actual world, not by a world constructed by the text. ${ }^{6}$ Texts are identified as C-texts or I-texts by their purpose, how they are made and used in a community. Peirce writes that science is a mode of life:

Science is to mean for us a mode of life whose single animating purpose is to find out the real truth, which pursues this purpose by a well considered method, founded on thorough acquaintance with such scientific results already ascertained by others as may be available, and which seeks co-operation in the hope that the truth may be found, if not by any actual inquirers, yet ultimately by those who come after them and who shall make use of their results. (CP 7.54)

Scientific inquiry as a mode of life is an activity that is important to its practitioners' sense of identity. The specific goals and ambitions of scientific inquiry distinguish it from other human endeavors. This influences how judgment is exercised, evidence admitted or rejected, and so on (Hookway 2000: 72). The late Wittgenstein (2009: §23) would call scientific inquiry a language-game that is part and parcel of a scientific form of life. Forms of life involve agreements in definitions, opinions, and judgments (ibid.: § 241-2). Scientific investigators have a substantive commitment to the truth that is accompanied by reflections on and commitment to a method (Ransdell 1977: 164-5). Historians share these commitments with other kinds of investigators - they, too, reflect on their methods, scrutinize their sources, and seek to support their claims with evidence (Tamm 2014: 276). This makes the historians' form of life a scientific one. Thus, historical texts are I-texts because they are intended to be used as sources of information about the past, and result from the intention to produce texts that provide such information.

Skeptics could argue that such intentions do not change anything because historiography employs rhetoric. Rhetoric is opposed to truth as well as proof, since its primary aim is effectiveness and persuasion. This non-referential interpretation of rhetoric comes from Nietzsche who treated rhetoric as a means for reflecting on truth outside the sphere of morality. According to the Aristotelian tradition, however, rhetoric encompasses different modes of proof for the purposes of persuasion. Within this tradition, argumentation and explanation deals with probabilities and plausibilities (Ginzburg 1999). Recent developments in rhetoric, such as Chaim Perelman's and Lucie OlbrechtsTyteca's (1969) new rhetoric, define rhetoric as "the study of discursive techniques 
allowing us to induce or to increase the mind's adherence to theses presented for its assent" (Perelman \& Olbrechts-Tyteca 1969: 4). On this view, dialectic ${ }^{7}$ and rhetoric are related: the former is a theory about the techniques of argumentation while the latter is a practical discipline about how dialectical techniques may be used to convince or persuade an audience (van Eemeren Frans et al. 2014: 261). In real-life settings, rhetoric often involves reasoning on the basis of non-analytic thinking, which is discursive, and aims to convince and rationally persuade the audience (ibid.: 261-2, 261n8). Rhetoric in this sense is neither antithetical to nor constrained by truth and proof. This view was partly inspired by Peirce's rhetorica speculativa, which studied the transmission of meaning from mind to mind, and from one state of mind to another by way of signs (olbrechts-Tyteca 1963). Thus, the concept of rhetoric employed by the skeptics is too narrow. The rhetorical dimension of historiography does not necessarily exclude it from the domain of truth.

49 Finally, the stylistic forms of historical narratives have no influence on the relationship between historiography and evidence. Narratives are not necessarily fictional. Scientific theories about the evolution of life or the big bang come in narrative forms, but this does not make them fictional. What matters is not the form of historiography, but its epistemic relation with the evidence (Tucker 2006: 92, 139). A skeptic could counter that even if this is the case, arguments are the primary means of rational persuasion, narratives, whether fictional or factual, are not arguments, and thus cannot persuade on rational grounds. But it is not at all clear that narratives and arguments are mutually exclusive. Some arguments make extensive use of narratives. For instance, an arguer may introduce a story, either factual or fictional, and, through the development of his or her argument, show how the story supports the argument's conclusion (see Hunt 2009; Govier \& Ayers 2012; Plumer 2015). Story structures can be used for organizing and making sense of the evidence in support of some conclusion or thesis (Pennington \& Hastie 1992, 1993). The four ways of emplotment distinguished by White could be seen as abstract story schemes that link together events and actions for presenting evidence (cf. Bex 2011). The links between events can be temporal or causal, and how the whole sequence hangs together is evaluated in light of our common knowledge about the way things can be normally expected to go in a familiar type of situation (Walton 2014: 35). Last but not least, it is also possible that narration itself may be a form of argumentation (see Fisher 1987). Thus, the non-argumentative nature of narratives is not a foregone conclusion, and cannot be used as a truism in support of the skeptical point of view.

\section{Dialogue and Truthlikeness in Historiography}

Let's begin by clearing up some possible misunderstandings. Truthlikeness is not probability. Probability, interpreted epistemically, measures the degree of seeming to be true. Truthlikeness measures the degree of being similar to the truth. Seeming to be true is concerned with appearances, similarity to the truth with objective facts about similarity or likeness. Probability and truthlikeness do not measure the same thing. The probability of the proposition "the number of planets is greater than or equal to 0 " is maximal, but it is not very close to the truth (Niiniluoto 1987: 183; Oddie 2014).

51 Truthlikeness is not vagueness. Suppose that, pace epistemicists (see Williamson 1994; Sorensen 2001), vagueness can be explained by treating absolute truth and absolute falsity as extrema on an interval of truth values representing degrees of truth. Such 
degrees are not degrees of closeness to the truth. Suppose Jones is $175 \mathrm{~cm}$. Consider two propositions:

1) Jones is exactly $170 \mathrm{~cm}$ tall.

2) Jones is tall.

The first should be absolutely false on any good theory of vagueness, while the second should have a relatively high truth degree if our reference class for tall people includes, say, those who are $185 \mathrm{~cm}$ and above. On the other hand, the precise but false (1) is closer to the truth, or more truthlike, than the vague (2) (Oddie 2014).

Truthlikeness is commonly taken not to refer to the acceptability or plausibility of a proposition (Hilpinen 1976: 23). I will, however, argue below that plausibility is one of the factors that goes into determining the truthlikeness of a historiographical proposition.

One of the biggest challenges for the concept of truthlikeness is the logical problem of truthlikeness, that is, the problem of giving an adequate account of the concept and determining its logical properties. A solution involves defining a measure of truthlikeness. No generally accepted measure has been found so far. Karl Popper (1962), who also put truthlikeness on the agenda of 20th century philosophy of science, defined two measures of truthlikeness in terms of the true and false consequences of a theory. The Tichy-Miller theorem (Tichy 1974; Miller 1974) demonstrated the inadequacy of Popper's measures. There have been attempts to remedy Popper's approach by defining a measure of truthlikeness in terms of the relevant consequences of a theory (see Burger \& Heidema 1994; Schurz \& Weingartner 1987). However, the applicability of relevancebased measures is limited (Gemes 2007). An alternative is to define a measure of truthlikeness in terms of similarities, determined by a similarity metric, between the possible worlds in which the proposition is true and the actual world (see Tichy 1974; Hilpinen 1976; Oddie 1986; Niiniluoto 1987). Besides disagreements over which similarity metric best captures the intuitive logical properties of the concept of truthlikeness, the main challenge of the similarity approach is the extension problem: how to appropriately extend a given measure of truthlikeness between possible worlds to propositions and larger units of evaluation (Schurz \& Weingartner 2010: 423)?

In light of these challenges, I will not attempt to define a measure of truthlikeness for historiography, opting instead to outline a theoretical basis from which such a measure could perhaps be defined. The aim is to present some of the factors that a measure of truthlikeness should take into account, and to show that Peirce's ideas provide a possible setting within which it could be defined.

\section{Reference and Semantic Dialogues}

Peirce's semeiotic would satisfy the first desideratum for a concept of truthlikeness, because it is referential, and broad enough to account for both textual as well as nontextual evidence. Throughout his life, Peirce formulated different versions of his semeiotic. I will rely on his final account, formulated between 1906 and 1910 (Atkin 2013), for presenting a referential theory of meaning as a viable alternative to the Saussurean paradigm favored by the skeptics. My reasons for relying on his final account are twofold: first, the early account was compatible with idealism (see Short 2007: 28ff), and second, his final, realist account draws an instructive parallel between semiosis, the overall process of sign interpretation (CP 5.484), and inquiry. 

sign "is something which stands to somebody for something in some respect or capacity" (CP 2.228). A sign gets its meaning from interpretation whereby someone determines which object the sign refers to, since the relation between a sign and its referent is by itself insufficient to ground representation (Misak 2004: 16; Pietarinen 2006: 32). Meaning is, according to Peirce, an irreducibly triadic relation where a sign, $s$, that refers to an object, $o$, according to an interpretant $i$ (W2: 224; Hookway 2000: 9, 126). To be more specific:

- Sign: is the signifying element in the triadic meaning-relation, the material underpinning in the form of some physical mark that is to be interpreted, that stands in a dyadic relation with some object, and can enter into another dyadic relation with some interpreter (CP 4.536; Ransdell 1977: 169).

- Object: is whatever is represented by the sign. This can be anything discussable, whether an individual or a collection, regardless of whether it exists or not (CP 2.232; EP 2: 498). The object determines the sign by placing constraints on the sign for the successful representation of that object with respect to some of its relevant characteristics.

- Interpretant: is the sign's more or less clarified meaning, the understanding of some sign-object relation reached as the end-point of an interpretative process where we have formed an idea of the difference that the sign's being true would make (Atkin 2013). It is determined by the sign via the features of the object, and the way the sign represents it.

Each of these three elements determines the others in the sense that each limits what the others may be: each object limits what may be a sign of it, and each sign limits what may be an interpretant of it (Short 2007: 167-8). This triadic relationship includes three referential relations: a sign directly refers to its object (also known as denotation, or the real thing it represents), indirectly refers to the characteristics common to the objects (also known as connotation, or, as Peirce calls it, the ground of the object), and indirectly refers to the interpretant which provides the totality of the facts known about the object (information, according to Peirce) (CP 2.418; W2: 59, 82).

In Peirce's late account, semiosis was patterned on his understanding of inquiry as a process that starts from a primitive or impoverished conception of the sign's object, and moves through intermediate stages toward a complete conception. At each intermediate stage of semiosis, both the object and interpretant are developed up to that point based both on previous stages and in anticipation of the presumed future course of interpretation that would culminate in a complete understanding of the object (Ransdell 1977: 168-9). The endpoint of this gradual process is the dynamic object (the real object as it is truly known at the end of semiosis) (Ransdell 1977: 169-70, 169n10-11; Hookway 1985: 139) which is accessed via the final interpretant or the true understanding of the dynamic object at the end of inquiry (see CP 8.184, 8.343) that interacts with the dynamic object in that it is a complete grasp of the dynamic object, captures all there is to know about it (Ransdell 1977: 173), and sets a normative standard for judging our interpretative responses to the sign because it is "the interpretant we should all agree on in the long run" (Hookway 1985: 139). The starting point of semiosis is the immediate interpretant (an understanding of the general features of a sign's meaning) (CP 5.473). Each intermediate step involves the dynamic interpretant (our understanding of the relationship between the sign and the dynamic object, as determined by the sign, at any intermediate stage of semiosis) that is connected with and constitutes the immediate object (the dynamic object as it appears at any interim stage of semiosis and differs from it due to partially mistaken or erroneous interpretations) (CP 4.536; Ransdell 1977: 169).

European Journal of Pragmatism and American Philosophy, VIII-2 | 2016 

(Short 2007: 200). It explains the difference between success and failure as well as truth and falsehood in interpretation. The success of an interpretant depends on reality, the dynamic object, not on representation, the immediate object (ibid.: 191). The dynamic object is incompletely knowable because "the Sign cannot express [that], which it can only indicate and leave the interpreter to find out by collateral experience" (CP 8.314). Collateral experience, in turn, is the interpretation of different signs as signs of the same object on the basis of experience that acquaints us with the object referred to by the sign (CP 8.178-9). Signs can be corrected and supplemented because the same dynamic object can be represented by different signs, and false or incomplete representations can contain enough truth to enable one to identify the object and provide a more accurate representation (Short 2007: 193-4).

But why think that collateral experience provides access to a mind-independent reality? Because experience is characterized by three basic features or categories: firstness is the mode of being of things that are without reference to anything else, such as appearances or qualities of feeling (CP 8.328-9); secondness is the mode of being of things with respect to a second but regardless of a third, such as the experiences of effort, struggle, causation, and resistance ( $\mathrm{CP} 8.328,8.330,1.325)$; and thirdness is the mode of being of things that bring a second and a third into a relation with each other by mediating between them, such as a law or a meaning that molds future behavior (CP 8.328, 1.343; W5: 304). Secondness is manifest in the experience of reality: "In the idea of reality, Secondness is predominant; for the real is that which insists upon forcing its way to recognition as something other than the mind's creation. [...] The real is active; we acknowledge it, in calling it the actual" (CP 1.325). This is the "Outward Clash" (CP 8.41) of something outside of our control on our experience that lies at the core of our concepts of reality and its mind-independent existence. It supports the conjecture that there is something that would exist as it is, irrespective of whether it is perceived, represented or experienced. That something is the dynamic object, the end-point or limit of semiosis, which ensures that the final interpretant, the interpretant we should all agree on in the long run, is at least potentially obtainable. This also accounts for the self-correcting nature of semiosis, which is based on the supplementation of signs.

But how is all this relevant to historiography where the past cannot be directly experienced? In his most famous trichotomy, Peirce distinguished between three kinds of signs: icons (signs that exhibit firstness and refer to their objects in virtue of their properties) (EP2: 291; CP 2.276), indices (signs that exhibit secondness and refer to their objects by being causally or otherwise connected to them) (CP 2.305), and symbols (signs that exhibit thirdness and refer to their objects by virtue of a law that causes a symbol to be interpreted as referring to that object) (EP2: 292). According to Peirce, all propositions are informational symbols. To convey genuine information, a proposition must be true:

If anything is true, definitely and decidedly true, that of which it is said to be true may be in some sense a creation of the mind. Still, once created, it must be in a measure independent of thought, so that merely denying the truth of what is asserted shall not destroy its truth. Otherwise, it does not mean anything to say it is true. (MS 463: 9)

63 An informative proposition conveys some truth in the sense of being connected to reality, independent of thought, because

the interpretant of [the proposition] [...] represents the proposition to be a genuine Index of a real object, independent of representation. For an index involves the 
existence of its Object. The definition adds that this Object is a Secondness, or real

Fact. (EP 2:278)

Although in all direct experience of reaction, an ego, a something within, is one member of the pair, yet we attribute reactions to objects outside of us. When we say 
that a thing exists, what we mean is that it reacts upon other things. That we are transferring to it our direct experience of reaction is shown by our saying that one thing acts upon another. [...] There are in experience occurrences; and in every experience of an occurrence two things are directly given as opposed, namely, what there was before the occurrence, which now appears as an ego, and what the occurrence forces upon the ego, a non-ego. This is particularly obvious in voluntary acts; but it is equally true of reactions of sense. (CP 7.534, 7.538)

The dialogical form of thought is, according to Peirce, in some ways akin to chess:

Thinking always proceeds in the form of a dialogue, - a dialogue between different phases of the ego, - so that, being dialogical, it is essentially composed of signs, as its Matter, in the sense in which a game of chess has the chessmen for its matter. (MS 298: 6)

70 Peirce's dialogical ideas can be modeled as games in the game-theoretic sense. He seems to have anticipated 20th century ludic developments in logic, viz. both the game-theoretic semantics of Jaakko Hintikka and his collaborators (see Saarinen 1979; Hintikka 1973) as well as dialogical logic, where dialogues are understood as games (Lorenzen 1958; Stegmüller 1964; Lorenzen \& Lorenz 1978). Peirce's semeiotic dialogues are compatible with Hintikka's semantic games, with the dialogue games of dialogical logicians, and have connections with game-theoretic pragmatics as well.

71 Semiosis, as outlined above, can be recast in game-theoretic terms. Game theory, as introduced by John von Neumann and Oskar Morgenstern (1944), and taken in an evolutionary direction by John Maynard Smith (Maynard Smith \& Price 1973; Maynard Smith 1982), is a collection of analytical tools for studying interactive processes between agents (Osborne \& Rubinstein 1994: 1). A benefit of treating semiosis as a semantic dialogue or game between an Utterer and an Interpreter is that this allows us to explain the goal-directed nature of semiosis without appealing to final causation, since goaldirected processes and purposeful activities, such as interpretation or inquiry, can be understood as games (Hintikka 2007: 94). Note that what follows is not a reconstruction of Peirce's own views, but a simplified development of them.

72 At the center of semiosis is a semantic dialogue, understood as a game-theoretic structure, which links signs with their objects, and language with reality (see Hintikka 1968, 1973). A semantic dialogue game is an interpretative process associated with a particular sign. There are two players, (quasi-)minds capable of interpretation, who can occupy the roles of Utterer, who transmits a sign, or Interpreter, who interprets it. These roles can be occupied be humans, animals or nature. Every semantic dialogue game is an attempt at the verification (by one of the players) or falsification (by the opposing player) of a given sign. Each player has a strategy, that is, a plan of action (Carmichael 2005: 4) that consists of instructions for choosing and evaluating alternative actions in light of what the player ought to choose (Pietarinen 2006: 84, 441, 442). For Peirce, meaning is a habit. This notion served a similar function for him as strategy does for games: both are exemplified by individual actions, both are plans of action for all possible circumstances, and both are involved in the interpretation of signs (see CP 5.400, 5.491; Pietarinen 2006: 82-4, 99-100). A player's strategy determines the course of interpretation that arrives at the meaning of a sign. Each player has a payoff that measures how well they are doing in all possible outcomes of the game. Payoffs determine which player wins (verifies or falsifies the sign), and which player loses. A sign is true if the Interpreter has a winning strategy in the correlated game, viz. if the Interpreter can always choose his moves (depending on what has happened before in the game) in a way that leads to his winning no matter what the 
Utterer does. The Interpreter wins if he can verify the truth of the sign, and loses otherwise, while the Utterer wins if he can falsify the sign, and loses otherwise (cf. Hintikka 1974: 52). This corresponds to the Tarskian notion of truth (see Hintikka \& Sandu 2011). The game ends once a sign has been assigned an object by the Interpreter's interpretant. The Interpreter wins if the sign represents the dynamic object as it truly is (if the sign is true of the object), and the Utterer wins if it does not. Hence semiosis, which determines the meaning of a sign, is an interactive process that gives rise to the totality of all actions, possible or actual, that do, might, will or would arise, as a consequence of playing the game in different contexts and settings (cf. Pietarinen 2007: 231-2).

One could argue that a dialogical interpretation of semiosis is not enough to guarantee the desired outcome in the way final causation does in Peirce's original account. But it is well-known that repeated plays or games in evolutionary settings tend to converge on stable equilibrium outcomes. Likewise, repetition or evolution can drive a semantic dialogue to a determinate and stable outcome. But the problem of equilibrium selection shows that there can be multiple stable outcomes of a game-like interactive process, and there seem to be no reliable criteria for determining which of these is chosen, or whether the chosen outcome is optimal. While this matter would require additional research, it seems to me not to be an insurmountable problem since Peirce's notion of final causation includes chance as an essential ingredient: chance provides the range of outcomes from which a selection is made (see Short 2007: 137). Thus, even if a dialogical treatment of semiosis omits some of Peirce's original metaphysical ideas, it seems sufficient for an ontologically modest referential theory of meaning that would not tip the fundamental ontological tradeoff as much in constructivism's favor as a would a theory that incorporates final causation. This would fulfill the first desideratum for truthlikeness in historiography: an ontologically modest referential theory of meaning.

\section{Inquiry, Truth, and Information-Seeking Dialogues}

Peirce's pragmatist theory of truth could satisfy both the second and the third desiderata outline above since it is fallibilist, links truth with inquiry, emphasizes the communal aspect of inquiry, and is closely connected with his semeiotics which accounts for both the interpretative and referential aspects of truth.

There are two closely interacting components in Peirce's theory of truth: reality and truth. Peirce defines the real as "that whose characters are independent of what anyone may think them to be" (W3: 271). Different definitions of truth can be found in Peirce's writings. The best known among these is the following:

Different minds may set out with the most antagonistic views, but the progress of investigation carries them by a force outside of themselves to one and the same conclusion. This activity of thought by which we are carried, not where we wish, but to a foreordained goal, is like the operation of destiny. No modification of the point of view taken, no selection of other facts for study, no natural bent of mind even, can enable a man to escape the predestinate opinion. This great law is embodied in the conception of truth and reality. The opinion which is fated to be ultimately agreed to by all who investigate, is what we mean by the truth, and the object represented in this opinion is the real. That is the way I would explain reality. (W3: 273)

Inquiry, like semiosis, is for Peirce a purposeful or goal-directed processes that evinces final causation (W3: 3,45$)$ : a proposition $p$ is true not solely because a community agrees 
that it is true, but because reality causes it to be true (see W3: 45). Mind-independent reality constrains the scientific community, which employs the scientific method, in a way that the inquiries and judgments of its members lead them, in the long run, to the belief as well as the agreement that $p$ is true; truth draws us toward itself (Ransdell 1977: 162; Hookway 2000: 47). This interpretation is supported by another one of Peirce's definitions of convergent truth: "Truth is that accordance of the abstract statement with the ideal limit towards which endless investigation would tend to bring scientific belief" (CP 5.565). Peirce's theory combines aspects of both the correspondence and coherence theories of truth (Haack 1976: 247). It is compatible with Tarski's notion of truth (Misak 2004: 127-9). It is fallibilist, since although inquirers will eventually reach the truth, at no point in the process is there any guarantee that their current beliefs will not be falsified by further evidence (Hookway 2000: 49-50, 77). On Peirce's account, then, a proposition at any stage of inquiry is only approximately true, i.e. truthlike, but not absolutely true. An absolutely true proposition is the ideal limit of inquiry. These ideas place Peirce within a broader tradition of thinking about truthlikeness that stretches from Nicholaus Cusanus to Karl Popper. ${ }^{8}$

The incorporation of final causation into theories of truth and inquiry tips the scales of the fundamental ontological tradeoff in favor of simpler constructionist alternatives. Misak (2004: 167-8) provides a modest and non-metaphysical interpretation of Peirce's theory of truth. On her reconstruction, truth depends on humans to the extent that it is a property of beliefs and beliefs are mental states of humans (ibid.: 132). Truth is convergence toward consensus at the end an indefinitely prolonged inquiry. It is not convergence in the sense of decreasing erroneousness of theories as they approach the truth, because convergence in this sense is about approaching the limit while consensus is about agreement (ibid:: 122-3). Convergent truth is objective not because it would correspond to reality by the end of inquiry but because it would be believed by a final community of inquirers at the end of inquiry (ibid.: 131-8).

While I find much to like about Misak's interpretation, her emphasis on consensus over convergence leaves no room for truthlikeness, and a slim ground for realism, because it downplays the constraining effect of reality on inquiry. An account of truthlikeness in historiography that takes Peirce's ideas as its starting point should retain ideas about convergence as approximation to the limit of truth while also making room for consensus as an additional mechanism that drives theories toward ever increasing truth. If such an account aspires to be metaphysically modest, then it should not appeal to final causation.

According to Peirce, inquiry starts with a cognitive problem or question and ends when the question has received an answer (W2: 471). This view of inquiry is reminiscent of the Socratic elenchus - inquirers interrogate nature and nature responds. Taking a clue from the dialogical interpretation of semiosis, I propose that inquiry, too, can be treated as a type of dialogue, viz. an information-seeking dialogue that constitutes inquiry (Hintikka \& Saarinen 1979; Hintikka \& Hintikka 1982: Hintikka 2007: 85). It can be understood as a two-player game, where one player is the Inquirer and the other is Nature. The goal is for one player, the Inquirer, to elicit or make explicit tacit information possessed by the other player, Nature. In game-theoretic terms, a game against nature is a game against an unreasoning entity whose strategic choices affect the other player's payoff, but which has no awareness of, or interest in, the overall outcome of the game (Straffin 1993: 56). The Inquirer can, among others things, make interrogative moves that consist in addressing questions to Nature. Nature's answers are assessed in light of the Inquirer's background 
knowledge. Questions are essentially requests for information, the specification of which is the specification of the epistemic state the questioner wants to be brought about (Hintikka 2007: 4-5, 89). They elicit tacit information. A question is more informative than another if answers to it are more informative than answers to another. In the context of natural science, questions can be thought of as observations, in the context of historiography, they can be thought of as explanatory hypotheses. The assumption is that for each question there is a certain set of potential answers. The availability or nonavailability of answers affects the Inquirer's strategies, and the set of potential answers is not limited by the Inquirer's language or conceptual scheme but by matters of fact (ibid:: 85-7). In historiography, answers can be construed as explanations of hypotheses by the evidence. Players' strategic considerations involve strategies of questioning as well as strategies for drawing further inferences from the answers. The Inquirer wins if he is able to verify the thesis expressed in his question.

As with semiosis and semantic dialogues, construing inquiry as a dialogue accounts for its goal-directedness without appealing to anything more than the strategic interactions of the participants. The method of science, according to Peirce, has two parts-the logic of science, which is voluntary since we can control the methods we apply in our reasoning, and experience which is involuntary (Misak 2004: 86). The methods and inference rules employed in an information-seeking dialogue are given by its definitory rules (Hintikka 2007: 7). These can be construed as codifying the shared methods of a scientific community. The strategic rules of an information-seeking dialogue tell the player how to play well in order to increase his or her chances of reaching the goal (ibid.). Each partial answer in the sequence of questions and answers in an information-seeking dialogue is a truthlike claim about some past event.

\section{Consensus, Plausibility and Persuasion Dialogues}

81 Historiography and evidence are linked by theories that identify the evidence as such in the first place. Competing historiographies are competing explanations of the evidence that posit different descriptions of historical events to explain the evidence (Tucker 2006: 93). Disagreements are due to the absence of knowledge of history, incomplete theories, and the underdetermination of evidence by theories (ibid.: 141ff). Information-seeking dialogues with the evidence of past events left by nature (understood here as including past human agents) account for the truth factor in truthlikeness. This should be distinguished from consensus, since, as Misak has argued, the two are different. In the context of historiography, however, consensus among a sufficiently large, uncoerced, and uniquely heterogeneous group of historians is an indicator of historical knowledge (ibid:: 6 , 20ff). Consensus is attained within the community through argumentation and persuasion. The evidence used for persuasive purposes is acquired in inquiry. If persuasion is successful, that is, if it manages to create consensus within the community, then the evidence as well as the associated explanatory hypothesis become part of historical knowledge. Thus convergence and consensus should be seen as two mechanisms that determine the truth and likeness (i.e. similarity) factors of truthlikeness in historiography, respectively.

In keeping with the dialogical approach adopted so far, persuasion within the community can be seen as a persuasion dialogue. This is a game between two players that starts with a conflict of opinions where one player holds one thesis or hypothesis, and the other either 
denies it or holds a contrary hypothesis. The overall goal is the resolution or clarification of an issue that is the cause of the conflict of opinions. This is done by proving or disproving the thesis (Walton 2008: 4-5, 11; Walton 2006a: 99). The underlying value of this type of dialogue is respect for the truth (Walton 2006a: 100). This supports the goal of resolving the conflict of interests by rational argumentation, which can involve or take the form of narration, in order to approach truth as an ideal. Movement toward the truth is evaluated through a process of collecting and testing evidence, done partly within an information-seeking dialogue, which leads to the rational acceptance or rejection of a player's thesis (ibid.: 128).

In natural sciences, the likeness of a proposition to the truth is increased or decreased by conducting experiments. What could fulfill a similar function in historiography? Following Georg Iggers, I suggest that we look to plausibility:

[P]lausibility obviously rests not on the arbitrary invention of an historical account but involves rational strategies of determining what in fact is plausible. It assumes that the historical account relates to a historical reality, no matter how complex and indirect the process is by which the historian approximates this reality. (Iggers 1997: 145) in hity. When an inquirer asserts a proposition and assents to it, viz. proclaims th it is true, he or she incurs commitments. The asserted proposition is presented as being truthlike. Asserting such a proposition forms part of the practice of cooperative inquiry within the scientific community. The proposition is directed both to one's contemporaries and to a potentially unlimited number of future inquirers. The scientific community is held together by the practice of assertion. He who asserts a proposition is trying to get other community members to believe it. Assertion is the vehicle for scientific debate. Once a public assertion is made, the asserted proposition is open to criticism. If the assertion was improper or the proposition false, then it is eventually withdrawn (see Hookway 2000: 65, 67-8, 70, 72-3, 144). The plausibility of an asserted proposition is settled by consensus reached through (narrative) argumentation in a persuasion dialogue. Rhetorical strategies, narrative structures, evidence - all of these are employed by the historian to increase the plausibility of his or her account in the eyes of the community.

Thus, historians belong to a community of researchers. They engage in informationseeking dialogues with their evidence in order to arrive at informative and true claims about the past. They address the (often partial) answers obtained from those dialogues to other community members, and try to persuade them of the truthlikeness of their thesis or explanatory hypothesis about the evidence. The likeness of those claims to the truth is determined by the outcomes of persuasion dialogues with other members of the community. The measure of truthlikeness of a claim about the past is determined by the 
informativeness of the answers obtained from information-seeking dialogues with the evidence, and its plausibility and rational acceptability at the end of a persuasion dialogue with other members of the scientific community.

\section{Conclusion}

87 Skeptics have argued that historiography cannot make truth-apt claims about the past because statements about the past are neither true nor false - historiography is akin to fiction and historians to authors of fiction in that both construct the worlds they write about. This view rests on a particular theory of meaning which is subject to criticism. Peirce's semeiotics and pragmatist theory of truth, ${ }^{9}$ reinterpreted in dialogical or gametheoretic terms, provide a plausible basis for defining a concept of truthlikeness for historiography in a way that accounts for its epistemic and methodological specificities. A plausible account of truthlikeness would go some way toward justifying optimistic fallible realism about historiography. Defining an actual measure of truthlikeness within the limits set by the framework introduced here is beyond the scope of the present essay. Similarity-based approaches define truthlikeness in terms of distances between possible worlds. Dialogues qua games can be viewed in standard form (represented by matrices) or in extensive form (represented by trees or directed graphs). One option would be to explore distance measures between the vertices of a graph as a basis for a measure of truthlikeness. Future research will have to determine the viability of this approach.

\section{BIBLIOGRAPHY}

ATKIN Albert, (2013), "Peirce's Theory of Signs," The Stanford Encyclopedia of Philosophy (Summer 2013 Edition), Edward N. Zalta, (ed.), Online: [plato.stanford.edu/archives/sum2013/entries/ peirce-semiotics/]. Accessed 13. November, 2016.

BACH Emmon, (1986), "Natural Language Metaphysics," Logic, Methodology and Philosophy of Science, Vol. VII: Proceedings of the Seventh International Congress of Logic, Methodology and Philosophy of Science , Ruth Barcan Marcus, Georg J. W. Dorn \& Paul Weingartner (eds.), Amsterdam, Elsevier, 573-95.

BARTHA Paul F. A., (2010), By Parallel Reasoning: The Construction and Evaluation of Analogical Arguments, Oxford, Oxford University Press.

BARTHES Roland, (1986 [1967]), “The Discourse of History,” Reprinted in The Rustle of Language, Richard Howard (trans.), Berkeley, University of California Press, 127-40.

BARTHES Roland, (1986 [1968]), “The Reality Effect,” Reprinted in The Rustle of Language, Richard Howard (trans.), Berkeley, University of California Press, 141-8.

BERLIN Brent, \& Paul KAY, (1969), Basic Color Terms: Their Universality and Evolution, Berkeley, University of California Press.

BEX J. Floris, (2011), Arguments, Stories, and Criminal Evidence: A Formal Hybrid Theory, Dordrecht, Springer. 
BLoch Marc, (1953), The Historian's Craft, Peter Putnam (trans.), New York, Vintage Books.

BROCK Jarret, (1980), “Peirce's anticipation of game-theoretic logic and semantics," Semiotics 1980: Proceedings of 5th Annual Meeting of the Semiotics Society of America, Michael Herzfeld \& Margot D. Lenhart (eds.), New York, Plenum, 55-64.

BURGER Isabella C., \& Johannes HeIDEMA, (1994), "Comparing Theories by Their Positive and Negative Contents," The British Journal for the Philosophy of Science, 45, 2, 605-30.

CARmichael Fiona, (2005), A Guide to Game Therory, Harlow, Financial Time Prentice Hall.

COLLINGWOod R. G., (1956), The Idea of History, Oxford, Oxford University Press.

CULLER Jonathan, (1976), Saussure, London, Fontana.

DE TIENNE André, (2006), “Peirce's Logic of Information," Seminario del Gruppo de Estudios Peirceanos, Universidad de Navarra, 28, September, Online: [unav.es/gep/

SeminariodeTienne.html]. Accessed November 30, 2016.

DEVITT Michael, (1983), “Dumett's Anti-Realism,” Journal of Philosophy, 80, 2, 73-99.

DEVITT Michael, (1991), Realism and Truth, 2nd edition, Oxford, Blackwell.

DeVITT Michael, \& Kim STERELNY, (1999), Language and Reality: An Introduction to Philosophy of Language, 2nd edition, Oxford, Blackwell Publishers.

DOLEžEL Lubomir, (1998), Heterocosmica: Fiction and Possible Worlds, Baltimore \& London, The Johns Hopkins University Press.

DOLEŽEL Lubomir, 2010), Possible Worlds of Fiction and History: The Postmodern Stage, Baltimore, The Johns Hopkins University Press.

DUMmETt Michael, (1959), “Truth,” Proceedings of the Aristotelian Society, 59, 1, 141-62.

DUMmetт Michael, (1991), The Logical Basis of Metaphysics, Cambridge, MA, Harvard University

Press.

DUMmETT Michael, (1993 [1978]), "What is a Theory of Meaning? (II)," reprinted in The Seas of Language, Oxford, Oxford University Press, 34-93.

DUMMETT Michael, (1993 [1983]), "Language and Truth," reprinted in The Seas of Language, Oxford, Oxford University Press, 117-46.

EWING A. C., (1934), Idealism: A Critical Survey, London, Methuen.

FISHER Walter R., (1987), Human Communication as Narration: Toward a Philosophy of Reason, Value, and Action, Columbia, University of South Carolina Press.

FRYE Northrop, (1957), Anatomy of Criticism, Princeton, Princeton University Press.

GEMES Ken, (2007), “Verisimilitude and Content,” Synthese, 154, 2, 293-306.

GINZBURG Carlo, (1999), History, Rhetoric, and Proof, Hannover and London, University Press of New England.

GOLDSTEIN Leon J., (1996), The What and the Why of History: Philosophical Essays, Leiden, Brill.

GOODMAN Nelson, (1978), Ways of Worldmaking, Indianapolis, Hackett.

GOVIER Trudy, \& Lowell AYERS, (2012), "Logic and Parables: Do These Narratives Provide

Arguments?," Informal Logic: Reasoning and Argumentation in Theory and Practice, 32, 2, 161-89.

European Journal of Pragmatism and American Philosophy, VIII-2 | 2016 
HAACK Susan, (1976), “The Pragmatist Theory of Truth," The British Journal of the Philosophy of Science, 27, 3, 231-49.

HAWKES Terence, (1977), Structuralism and Semiotics, London, Methuen \& Co.

HEIDER Eleanor R., (1971), “'Focal' Color Areas and the Development of Color Names,”

Developmental Psychology, 4, 3, 447-55.

HEIDER Eleanor R., (1972), “Universals in Color Naming and Memory,” Journal of Experimental Psychology, 93, 1, 10-20.

HINTIKKA Jaakko, (1968), “Language-Games for Quantifiers,” Nicholas Rescher (ed.), Studies in Logical Theory, Oxford, Basil Blackwell, 46-72.

HINTIKKA Jaakko, (1973), Logic, Language-Games and Information: Kantian Themes in the Philosophy of Logic, Oxford, Clarendon.

HINTIKKA Jaakko, (1979 [1974]), “Quantifiers vs. Quantification Theory,” reprinted in Game-

Theoretic Semantics: Essays on Semantics by Hintikka, Carlson, Peacocke, Rantala, and Saarinen, Dordecht, D. Reidel Publishing Company, 49-79.

HINTIKKA Jaakko, (2007), Socratic Epistemology: Explorations of Knowledge-Seeking and Questioning, Cambridge, Cambridge University Press.

HINTIKKA Jaakko, \& Merrill B. HINTIKKA, (1982), “Sherlock Holmes Confronts Modern Logic: Toward a Theory of Information-Seeking Through Questioning," in E. M. Barth \& J. L. Martens (eds.), Argumentation: Approaches to Theory Formation, Amsterdam, John Benjamins B. V., 55-76.

HINTIKKA Jaakko, \& Esa SAARINEN, (1979), “Information-Seeking Dialogues: Some of Their Logical Properties," Studia Logica: An International Journal for Symbolic Logic, 38, 4, 355-63.

HINTIKKA Jaakko, \& Gabriel SANDU, (2011), “Game-Theoretical Semantics," in Johan van Benthem \& Alice ter Meulen (eds.), Handbook of Logic and Language, 2nd edition, London, Elsevier, 415-65. HILPINEN Risto, (1976), “Approximate truth and truthlikeness,” in Marian PrzełĘcki, Klemens Szaniawski \& Ryszard Wójcicki (eds.), Formal Methods in the Methodology of Empirical Sciences: Proceedings of the Conference for Formal Methods in the Methodology of Empirical Science, Warsaw, June 17-21, 1974, Dordrecht, D. Reidel, 19-42.

HILPINEN Risto, (1982), "On C. S. Peirce's theory of the proposition: Peirce as a precursor of gametheoretical semantics," The Monist, 65, 2, 182-8.

HILPINEN Risto, (2004), "Peirce's logic," in Dov M. Gabbay, \& John Woods (eds.), Handbook of the History and Philosophy of Logic. Vol. 3: The Rise of Modern Logic From Leibniz to Frege, Amsterdam, Elsevier, 623-70.

HоOKWAY Christopher J., (1985), Peirce, London \& New York, Routledge.

ноокWAY Christopher J., (2000), Truth, Rationality, and Pragmatism: Themes From Peirce, Oxford, Clarendon Press.

HUNT Lester H., (2009), "Literature as Fable, Fable as Argument," Philosophy and Literature, 33, 2, $369-85$.

IGGERS Georg G., (1997), Historiography in the Twentieth Century: From Scientific Objectivity to the Postmodern Challenge, Hanover, Wesleyan University Press.

JAMESON Frederic, (1972), The Prison-House of Language, Princeton, Princeton University Press. JENKINS Keith, (2000), “A Postmodern Reply to Perez Zagorin,” History and Theory, 39, 2, 181-200. 
JENKINS Keith, \& Alun MUNSLOW, (2004), "Introduction," in Keith Jenkins, \& Alun Munslow (eds.), The Nature of History Reader, London \& New York, Routledge, 1-18.

Kosso Peter, (1992), “Observation of the Past," History and Theory, 31, 1, 21-36.

LAUDAN Larry, (1981), “A Confutation of Convergent Realism,” Philosophy of Science, 48, 1, 19-49.

LE GOFF Jacques, (1992), History and Memory, Steven Rendall \& Elizabeth Claman (trans.), New York, Columbia University Press.

LORENZEN Paul, (1958), “Logic und Agon,” Arti del XII Congresso Internationale de Filosofia, Venezia, 187-94.

LORENZEN Paul, \& Kuno LOREnZ, (1978), Dialogische Logik, Darmstadt, Wissenschaftliche Buchgesellschaft.

MAYNARD SMITH John, (1982), Evolution and the Theory of Games, Cambridge, Cambridge University Press.

MAYNARD SMITH John, \& George R. PRICE, (1973), “The Logic of Animal Conflict,” Nature, 246, 15-8. MILLER Alexander, (2014), "Realism," Stanford Encyclopedia of Philosophy (Winter 2014 Edition), Edward N. Zalta (ed.), Online: [plato.stanford.edu/archives/win2014/entries/realism/]. Accessed 13. November, 2016.

MILLER David, (1974), “Popper's Qualitative Theory of Verisimilitude," The British Journal for the Philosophy of Science, 25, 2, 166-77.

MISAK Cheryl J., (2004), Truth and the End of Inquiry: A Peircean Account of Truth, Oxford, Clarendon Press.

MUNSLOW Alun, (1997), Deconstructing History, London \& New York, Routledge.

MURPHEY Murray G., (1973), Our Knowledge of the Historical Past, Indianapolis \& New York, BobbsMerrill.

MURPHEY Murray G., (1994), Philosophical Foundations of Historical Knowledge, Albany, State University of New York Press.

NIINILUoтo Ilkka, (1987), Truthlikeness, Dordrecth, D. Reidel Publishing Company.

ODDIE Graham, (1986), Likeness to Truth, Dordrecht, D. Reidel Publishing Company.

ODDIE Graham, (2014), “Truthlikeness,” The Stanford Encyclopedia of Philosophy (Summer 2014

Edition), Edward N. Zalta. (ed.), Online: [plato.stanford.edu/archives/sum2014/entries/ truthlikeness/]. Accessed 13. November, 2016.

OLBRECHTS-TYTECA Lucie, (1963), "Recontre avec la rhétorique," La théorie de l'argumentation: Perspectives et application, National Belge de Recherches de Logique (ed.), Louvain-Paris, Editions Nauwelaerts, 3-18.

OSBORNE Martin J., \& Ariel RUBINSTEIN, (1994), A Course in Game Theory, Cambridge, MA, The MIT Press.

PAVEL Thomas G., (1986), Fictional Worlds, Cambridge, Cambridge University Press.

PEIRCE Charles S., (1931-1958), Collected Papers of Charles Sanders Peirce, Vols. 1-8, eds. Charles Hartshorne, Paul Weiss \& Arthur W. Burks, Cambridge, MA, Harvard University Press. Abbreviated by CP followed by volume and paragraph number. 
PEIRCE Charles S., (1967), Manuscripts in the Houghton Library of Harvard University, Abbreviated by MS, followed by catalogue and sheet number.

PEIRCE Charles S., (1982-), Writings of Charles S. Peirce: A Chronological Edition, Vols. 1-8, Max Fisch, Edward C. Moore, Christian J. W. Kloesel et al. (eds.), Bloomington and Indianapolis, Indiana University Press. Abbreviated by W, followed by volume number and page number.

PEIRCE Charles S., (1992-1998), The Essential Peirce: Selected Philosophical Writings, Vols. 1-2, Nathan Houser, Christian J. W. Kloesel, \& the Peirce Edition Project (eds.), Abbreviated by EP followed by volume number and page number.

PENNINGTON Nancy, \& Reid HASTIE, (1992), “Explaining the Evidence: Tests of the Story Model for Juror Decision Making," Journal of Personality and Social Psychology, 62, 2, 189-206.

PENNINGTON Nancy, \& Reid HASTIE, (1993), “The Story Model for Juror Decision Making," in Reid Hastie (ed.), Inside the Juror: The Psychology of Juror Decision Making, Cambridge, Cambridge University Press, 192-221.

PERELMAN Chaim, \& Lucie OlBRECHTS-TYTECA, (1969), The New Rhetoric: A Treatise on Argumentation, John Wilkinson \& Purcell Weaver (trans.), Notre Dame, University of Notre Dame Press.

PIETARINEn Ahti-Veikko, (2006), Signs of Logic: Peircean Themes on the Philosophy of Language, Games, and Communication, Dordrecht, Springer.

PIETARINEN Ahti-Veikko, (2007), "The Semantics/Pragmatics Distinction from the Game-Theoretic Point of View," in Ahti-Veiko Pietarinen (ed.), Game Theory and Linguistic Meaning, Amsterdam, Elsevier, 229-42.

PLUMER Gilbert, (2015), “On Novels as Arguments," Informal Logic: Reasoning and Argumentation in Theory and Practice, 35, 4, 488-507.

POPPER Karl R., (1962), Conjectures and Refutations: The Growth of Scientific Knowledge, New York, Basic Books.

PUTNAM Hilary, (1978), Meaning and the Moral Sciences, London, Routledge and Kegan Paul.

RANSDELL Joseph, (1977), “Some Leading Ideas of Peirce's Semiotic,” Semiotica, 19, 3-4, 157-78.

RESCHER Nicholas, (1977), Dialectics: A Controversy Oriented Approach to the Theory of Knowledge, Albany, State University of New York Press.

SAARINEN Esa, (ed.), (1979), Game-Theoretic Semantics: Essays on Semantics by Hintikka, Carlson, Peacocke, Rantala, and Saarinen, Dordrecht, D. Reidel.

SAUSSURE Ferdinand de, (1959), Course in General Linguistics, eds. Charles Bally and Albert Sechehaye, tr. Wade Baskin, New York, Philosophical Library.

SCHURz Gerhard, \& Paul WeIngARTNER, (1987), "Verisimilitude Defined by Relevant ConsequenceElements," in Theo A. F. Kuipers (ed.), What is Closer-to-the-Truth? A Parade of Approaches to Truthlikeness, Amsterdam, Rodopi, 47-78.

sCHURz Gerhard, \& Paul WEINGARTNER, (2010), “Zwart and Fraassne's Impossibility Theorem Holds for Possible-World-Accounts but Not for Consequence-Accounts of Verisimilitude," Synthese, 172, 3, 415-36.

SEBEOK Thomas A., (2001), "Signs: An Introduction to Semiotics," 2nd edition, Toronto, University of Toronto Press.

SHORT T. L., (2007), Peirce's Theory of Signs, Cambridge, Cambridge University Press. 
SORENSEN Roy, (2001), Vagueness and Contradiction, New York, Oxford University Press.

STALNAKER Robert C., (1967), "Events, Periods, and Institutions in Historians' Language," History and Theory, 6, 2, 159-79.

STRAFFIN Philip D., (1993), Game Theory and Strategy, Washington, The Mathematical Association of America.

STEGMÜLLER Wolfgang, (1964), "Remarks on the Completeness of Logical Systems Relative to the Validity-Concepts of P. Lorenzen and K. Lorenz.," Notre Dame Journal of Formal Logic, 5, 2, 81-112.

SWOYER Chris, \& Francesco ORILIA, (2011), "Properties," The Stanford Encyclopedia of Philosophy (Fall 2011 Edition), Edward N. Zalta (ed.), Online: [plato.stanford.edu/archives/fall2011/entries/ properties/]. Accessed 13. November, 2016.

TAMM Marek, (2014), “Truth, Objectivity and Evidence in History Writing," Journal of the Philosophy of History, 8, 2, 265-90.

TICHY Pavel, (1974), “On Popper's Definitions of Verisimilitude,” The British Journal for the Philosophy of Science, 25, 2, 155-60.

TUCKER Aviezer, (2006), Our Knowledge of the Past: A Philosophy of Historiography, Cambridge, Cambridge University Press.

VAN DEN AKKEN Chiel, (2013), "Mink's Riddle of Narrative Truth," Journal of the Philosophy of History, $7,3,346-70$.

VAN EEMEREN Frans, GARSSEN Bart, KRABBE C. W. Erik, SNOECK HENKEMANS A. Francisca, VERHEIJ Bart, \& Jean H. M. WAGEMANS, (2014), Handbook of Argumentation Theory, Dordrecht, SpringerReference. VON NEUMANN John, \& Oskar MORGENSTERN, (1953), Theory of Games and Economic Behavior, 3rd edition, Princeton, Princeton University Press.

WALTON Douglas, (2006a), Dialog Theory for Critical Argumentation, Amsterdam/ Philadelphia, John Benjamins Publishing Company.

WALTON Douglas, (2006b), Fundamentals of Critical Argumentation, Cambridge, Cambridge University Press.

WALTON Douglas, (2008), Informal Logic: A Pragmatic Approach, 2nd edition, Cambridge, Cambridge University Press.

WALTON Douglas, (2014), “Argumentation Schemes for Argument from Analogy," Henrique Jales Ribeiro (ed.), Systematic Approaches to Argument from Analogy, Cham, Springer, 23-40.

WHITE Hayden, (1973), Metahistory: The Historical Imagination in Nineteenth Century Europe, Baltimore \& London, The Johns Hopkins University Press.

WHITE Hayden, (1978), Tropics of Discourse: Essays in Cultural Criticism, Baltimore \& London, The Johns Hopkins University Press.

WILLIAMSON Timothy, (1994) Vagueness, London \& New York, Routledge.

WITTGENSTEIN Ludwig, (2009), Philosophical Investigations, 4th edition, G. E. M. Anscombe, P. M. S. Hacker \& Joachim Schulte (eds. and trans.), Oxford, Wiley-Blackwell.

ZAGORIN Perez, (1999), "History, the Referent, and Narrative: Reflections on Postmodernism Now," History and Theory, 38, 1, 1-24. 


\section{NOTES}

1. This is the conclusion of Larry Laudan's (1981) pessimistic induction.

2. It seems that NEC could be interpreted in different ways. A strong interpretation would deny the existence of objects and their properties in some domain (e.g. there are no natural numbers qua abstract objects). A weaker interpretation would deny the existence of objects but could affirm the existence of properties attributed to them (e.g. there are no natural numbers qua abstract objects, but their properties belong to mental constructions).

3. The name "postmodern challenge" comes from Lubomir Doležel (2010: ix).

4. I would like to thank an anonymous reviewer for pointing this out to me.

5. Michael Riffaterre tried to add this fallacy to the panoply of informal fallacies (see Pavel 1986: 118).

6. The logic and metaphysics of time are complex issues that I cannot enter into here. Regarding reference to the past, suffice it to say that historical discourse employs natural language, and one of the metaphysical presuppositions of natural language semantics seems to be that past moments of time and past places can be the referents of ordinary language expressions (see Bach 1986).

7. Dialectic is understood here as the art of rational argument by conversation, not as a Hegelian comprehension of the unity of opposites (see Walton 2006a: 47, 70).

8. See Niiniluoto (1987: 165-71). For a dissenting view, see Misak (2004: 119-20, 122).

9. The realist theory of truth I have derived from Peirce's remarks differs notably from how pragmatist theories of truth have been traditionally described. I would argue that the theory outlined here can still be called pragmatist because truth, according to Peirce, at least as I have interpreted him here, is neither correspondence nor coherence nor consensus, but the fallible "opinion which is fated to be ultimately agreed upon by all who investigate" (W3: 273). In other words, the account outlined here deserves to be called pragmatist because it retains the central tenets of Peirce's views, viz. that truth is related to inquiry, connected with the practices of inquirers, and fallible.

\section{ABSTRACTS}

Truthlikeness in historiography would allow us to be optimistic fallible realists about historiography - to hold that historical knowledge is about the past, true albeit fallible, and can increase over time. In this paper, three desiderata for a concept of truthlikeness in historiography will be outlined. One of the main challenges for truthlikeness is historiographic skepticism which holds that historiography is indistinguishable from fiction and cannot therefore furnish us with true knowledge about the past. Such skepticism rests on the postmodern challenge, which will be criticized on the grounds that it rests on an implausible theory of meaning. It will be shown that Peirce's semeiotic and pragmatist theory of truth, interpreted dialogically or game-theoretically, provides a suitable framework within which to pursue the project of defining a concept of truthlikeness for historiography. Finally, directions for possible future research into truthlikeness in historiography, including ways of defining a measure of truthlikeness, will be considered. 
AUTHOR

OLIVER LAAS

Tallinn University

oliver.laas[at]gmail.com 